\title{
Providing facilities to improve accessibilities to railway station for all
}

\author{
Wanrawee Nawagawong ${ }^{1}$ and Wasaporn Techapeeraparnich ${ }^{* 2}$ \\ ${ }^{1}$ Civil and Environmental Engineering Department, 25/25 Phutthamonthol Sai 4, \\ Phutthamonthol, Salaya, Nakhonpathom, Thailand, 73170.
}

\begin{abstract}
Thailand is now entering to an aging society, as the number of elderly will increase to 25.2 million people in the year 2030 [1]. From the statistics of National Statistical office 2007, the number of people with disabilities (PwDs) is approximately $2.9 \%$ or 1.7 million people of the total population. The Thai government has recently enacted many policies and acts specifically to equal the right of these people to be able to live like a normal person. One of the aspects of these acts is enabling them to access transportation services without difficulties. As Thailand has recently invested large amount budget on developing many railway projects, thus this is an important opportunity to enhance the design standard of transportation facilities to meet the demands of all types of users. This research is aimed to compare the laws and guidelines of railway station and facilities designed for all at international level and to explore the principles of railway station design that used for railway station design in order to make the recommendation for Thai railway station design to improve accessibility in terms of designs and additional facilities.
\end{abstract}

\section{Introduction}

It is reported that 1 in $8 \mathrm{U} . \mathrm{S}$. adults aged 35 to 64 is a disability and 1 in 3 adults aged 65 or older has a disability, meanwhile the population is approximately 309 million [2]. Similar to the European Union, the number of elderly and disabled people is currently estimated between $60-80$ million people and disability are highest in the age group 65 over [3].Thailand is not different to United State of America. We are entering into aging society and people with disabilities (PwDs) caused from aging keep increasing. According to a statistic from the Office of National Economic and Social Development Board (2015), Thailand will have the elderly at approximately $21.2 \%$ in year 2025 and will increase to $25.2 \%$ in year 2030 , at which Thailand will become a complete aging society. WHO's reported that disability is usually defined in terms of restrictions on the ability to perform activities of daily living (ADL) or the inability to function independent [4]. The limited of mobility is common to unhealthy elderly and 1 of 5 of elderly will have difficulty in mobility according to the age and occurring since middle age (5064 years old).

\footnotetext{
${ }^{2}$ Certified from Mahidol University Institutional Review Board Committee project no. 2016-206.0912 dated 6 March 2017

*Corresponding author: wasaporn.tac@mahidol.ac.th
} 
The main casual symptoms cited were "pain in the legs or foot" then "shortness of breath" [5]. Besides elderly problems, the record of Department for Empowerment of Persons with Disabilities as of October 2016 reported the statistic of registration of persons with disabilities approximate 1.7 million people across the country.

Recently, The Thai government has invested huge budget in the development of railway transportation development. Many projects are now progressing on feasibility study, design or even though under construction. Economic Intelligence Center reported that Thailand's Transport Infrastructure Investment Plan (2013-2020) has a total investment of 2 Trillion Baht including strategic development and improvement of transport system to raise mobility approximate 6 billion (60\% of 2 Trillion Baht), such as Rapid Transit System Development Project for Urban Passenger Transport System and transport development project to linking core economic areas within the country[6]. Thus this is an important opportunity to enhance the standard of transportation facilities to meet the demands of all types of users. This research is aimed to compare the laws and guidelines of railway station and facilities designed for

all at international level and to explore the principles of railway station design that used for railway station design in order to make the recommendation for improving Thai standard to improve accessibility of these people to the railway station.

\section{Literature review}

To improve the accessibility for all, it is necessary to understand the meaning of "for all". The British Standards Institute (2005) defined "for all" as "the design of mainstream products and/or services that is accessible to, and usable by, as many people as reasonably possible without the need for special adaptation or specialized design.” EIDD Design for AllEurope also defined that design for all is a design for human diversities, social inclusion and equality and aims to enable all people to have equal opportunities to participate in every aspect of society [7]. Therefore, the meaning term of "for all" means "designed for people of all ages in the community without restrictions on age, gender, children, the sick people, the elderly, pregnant women and PwDs". The Thai government has enacted Building Control Act 2005 (No.5) which effective from 2005 that the design and calculation of buildings must provide all facilities for PwDs and elderly as required[8]. The types of building that must provide the facilities to PwDs and the elderly are:

1) Hospital, health center, government building, State-owned enterprises buildings, educational institutions, libraries, museum, massed transit stations such as airports, train stations, bus stations, wharf which area of the building purpose is using for the public over 300 square meters.

2) Office, theater, hotel, auditorium, stadium, shopping center, department store which area of the building purposes is using for the public over 2,000 square meters.

Likewise, the Ministerial Regulations of Designing or Equipment Facilities of the Ministry of Transportation to enable people with disabilities to access and utilize (2013) states that railway station must provide facilities for PwDs and elderly as follows [9]. 1) Door for PwDs 2) Seating or wheelchair parking for PwDs 3) Ramp 4) Handrail 5) Surface floor for visual disability 6) Toilet with PwDs assistive 7) Lift 8) Telephone with PwDs assistive 9) Parking for PwDs and 10) PwDs facilities signage Additionally, The Thai government offers incentives to building owner to whom who provide facilities to accommodate to PwDs and elderly people according to the Act of Promote and Improve the Quality of Life of the Disabled (2008) [10]. There are many laws already enforced in Thailand However, the details of types, numbers, dimension of the assistive infrastructure and facilities are still undeveloped.

Many types of people are living in a society such as child, adult, elderly or even PwDs. All of those people have the right to access any public infrastructure as equality policy. To do this, PwDs may need the assistive facilities more than ordinary people. According to the International Classification of Functioning, Disability, and Health (ICF) had set up a framework using in inter-communication collaborative practice and person-centered care and it is the 
disability classification by physical model. The two major parts of ICF framework are 1) Functioning \& disability: It means the impairments of body functions such as movement disabilities, learning disabilities and it effects to daily activities of individual PwDs. 2) Contextual Factors: this part means the participation or involvement of people participation in society and environment[11].

Similar to Disability Rehabilitation Act 1991 [12] issued by Ministry of Health, disabilities can be classified into 6 types. The details as shown in Table 1. below.

Table 1. Type of PwDs in Thailand [12]

\begin{tabular}{|c|l|l|}
\hline Item & Type of PwDs & \multicolumn{1}{c|}{ Characteristics } \\
\hline 1 & Vision disability & $\begin{array}{l}\text { The individual who has limitation in participating activities in } \\
\text { daily life or limited to participate in social activities, which is a } \\
\text { result of vision impairments. }\end{array}$ \\
\hline 2 & Hearing disability & $\begin{array}{l}\text { The individual who has the limited in the participation of activities } \\
\text { in daily life or limited to participate in social activities and loses } \\
\text { the ability of hearing, which is a result of hearing. In this case, it is } \\
\text { included the impairment of interpretation. }\end{array}$ \\
\hline 3 & Mobility disability & $\begin{array}{l}\text { The individual ability by prosthesis implantation or their physical } \\
\text { aid this case including a wheelchair. }\end{array}$ \\
\hline 5 & Mental or behavioral disability & $\begin{array}{l}\text { The individual who has the limited in participation activities in } \\
\text { daily life or to participate in social activities, which is a result of } \\
\text { deficiency or abnormality of mind. }\end{array}$ \\
\hline & Intellectual disability & $\begin{array}{l}\text { The individual who has the limited in participation activities in } \\
\text { daily life or to participate in social activities, which is a result of } \\
\text { cognitive impairments and the development slower than usual. }\end{array}$ \\
\hline
\end{tabular}

Remark: This research is going to study for 3 types of disabilities including vision, hearing and mobility disabilities only.

\section{Design principle for public transportation facilities}

The widely accepted design principle of building or facility including public transportation facilities and station design to enable the use of all are 1) Universal Design 2) Barrier Free Design and 3) Service Design.

Universal Design: Universal design means the design of composition and environment that allow everyone to access regardless of age, size, ability or disability matters. The concept of Universal Design is trying to eliminate the certain barriers that limit the usability of environment for people with disabilities. Universal Design was developed from "Barrier Free" and "Assistive Technology" (Peloquin, 1994). The following are main ideas of universal design. 1) EquiTable use 2) Flexible in use 3) Simple and intuitive 4) Perceptible Information 5) Tolerance for error 6) Low physical effort 7) Size and space for approach and use

Barrier Free Design: United Nation (UN) defined that barrier-free could fulfill the needs of all people equally. Barrier free design considers holistically allowing the people with disabilities (people with wheelchair or less mobility) to access any places such as buildings, restrooms, transportation stations, etc. or allow them to easily use the facilities[14].

Service Design: Service design is multi-disciplinary and integrative field. It helps to both innovate and improve services to make them more useful, usable, desirable for clients, as well as more efficient and effective for organizations. Service design consists of five concepts as following 1) User centered 2) Co-creative 3) Sequencing 4) Evidencing 5) Holistic

Therefore if people with reduced mobility is able to access to public facilities, it will be a benefit to all such as families with small children or prams or push-chair or people having a lot of luggage. People, carrying a suitcase in each hand, have difficulty entering a station if the door does not open automatically. Thus, the requirements of those people need to be considered for railway facilities design. Besides this issue, personal safety while waiting or departing at railway stations where criminals were tended to hide around the area [18]. Both accessibility 
and criminal's problems became the policy or legislation of EU countries which will be enforced to all licensed train and station operators to strictly implement.

\section{Methodology}

This research was firstly conducted by reviewing documents. The documents are standards and guidelines for railway stations and facilities design from different countries. Then the list is summarized and compared. List of standard and guidelines gathered and reviewed in this study are as shown in Table 2 .

Table 2. List of standards and guidelines reviewed and considered in this study.

\begin{tabular}{|c|c|c|c|}
\hline Item & Standard Name & Issued by & Country \\
\hline 1. & $\begin{array}{l}2006 \text { Americans with Disabilities Act (ADA) Standards } \\
\text { for Transportation Facilities[15] }\end{array}$ & $\begin{array}{l}\text { United State } \\
\text { Access board }\end{array}$ & $\begin{array}{c}\text { The United State } \\
\text { of America }\end{array}$ \\
\hline 2. & $\begin{array}{l}\text { COMMISSION REGULATION No } 1300 / 2014 \text { of } 18 \\
\text { November } 2014 \text { on the technical specifications for } \\
\text { interoperability relating to accessibility of the Union's rail } \\
\text { system for persons with disabilities and persons with } \\
\text { reduced mobility (EU) [19] }\end{array}$ & $\begin{array}{l}\text { European Union } \\
\text { Agency for Railway }\end{array}$ & $\begin{array}{l}\text { The European } \\
\text { Union }\end{array}$ \\
\hline 3. & $\begin{array}{l}\text { Accessibility for the Disabled } \\
\text { A Design Manual for a Barrier Free Environment [14] }\end{array}$ & $\begin{array}{l}\text { United Nation } \\
\text { (UN) }\end{array}$ & - \\
\hline 4. & $\begin{array}{l}\text { Disability Standards for Accessible Public Transport } 2002 \\
\text { (DSAPT) [20] }\end{array}$ & $\begin{array}{c}\text { Australian } \\
\text { Government }\end{array}$ & Australia \\
\hline 5. & 2007 Facility Accessibility Design Standard [21] & City of London & Canada \\
\hline 6. & $\begin{array}{l}\text { Ministerial Regulations of Designing or Equipment } \\
\text { Facilities of the Ministry of Transportation to enable } \\
\text { people with disabilities to access and utilize [9] }\end{array}$ & Thai government & Thailand \\
\hline
\end{tabular}

Standards listed above, some of them for example 2006 Americans with Disabilities Act (ADA) was based on "Barrier Free Design" similar to Accessibility for the Disabled A Design Manual for a Barrier Free Environment which was developed by United Nation (UN). While European Union Agency for Railway had developed guideline with a broader consideration of both Universal and Barrier Free Design. The study of is the evidence that even by reducing the gap between the train and platform at underground stations and widening the doors of trains according to Universal Design and Barrier Free Design can have a significant impact in saving the train dwell time[21]. The results of research found that these are able to increase the benefit-cost ratio of a project and also specified that improving passenger mobility and network efficiency research indicates a cost benefit to operators.

\section{Questionnaire and sampling}

After reviewing the guidelines and standards, the researcher developed the questionnaire to ask respondents to assess the importance of facilities which are developed from the comparison of standards and guidelines. Data is collected from sampling group which composed of all types of prospective passengers. The result of this part will be preliminary analyzed by using descriptive statistic. The research sampling groups were identified as shown in Table 3. below.

Table 3. Research sampling groups

\begin{tabular}{|c|l|c|}
\hline Type & \multicolumn{1}{|c|}{ Description } & Quantity \\
\hline 1 & Visual disability & 5 \\
\hline 2 & Hearing or meaningful disability & 5 \\
\hline 3 & Mobility disability & 5 \\
\hline 4 & General passenger & 5 \\
\hline 5 & Elderly passenger & 5 \\
\hline 6 & Passenger with luggage & 5 \\
\hline 7 & Passenger with pram & 5 \\
\hline 8 & Passenger who travel with children (age under 10 years old) & 5 \\
\hline & Total & 40 \\
\hline
\end{tabular}




\section{Findings}

After reviewing standard guidelines from different countries, the researcher then made a comparison of the components of public transportation station facilities as shown in Table 4. It is found that these standards were moderately similar; by way of it concentrates on accessibility for all and sustainability of 2 groups those are 1) Compulsory facilities that are necessary for stations function design and safety reason regardless of station size. 2) Optional facilities that will be able to assist passengers to travel safer, more accessible and infrastructure usage. The facilities indicated by the above standards able to be compared as shown in Table 4 .

Table 4. Thailand Compulsory of public transportation and comparison to international standards

\begin{tabular}{|c|c|c|c|c|c|c|c|}
\hline Item & Facility name & ADA $^{1}$ & $\mathbf{E U}^{2}$ & $\mathbf{U N}^{3}$ & $\mathbf{C A}^{4}$ & DSAPT $^{5}$ & Thai $^{6}$ \\
\hline 1 & Parking & $\checkmark$ & $\checkmark$ & $\checkmark$ & $\checkmark$ & & $\checkmark$ \\
\hline 2 & Street furniture & & & $\checkmark$ & $\checkmark$ & $\checkmark$ & \\
\hline 3 & $\begin{array}{l}\text { Areas of refuge Emergency exit } \\
\text { and fire evacuation and area of } \\
\text { rescue assistance }\end{array}$ & $\checkmark$ & & & $\checkmark$ & & $\checkmark$ \\
\hline 4 & Passenger loading zone & $\checkmark$ & & & $\checkmark$ & & \\
\hline 5 & Bus boarding and alighting areas & $\checkmark$ & & & & $\checkmark$ & \\
\hline 6 & $\begin{array}{l}\text { Level track crossing at station or } \\
\text { Overpass for PwDs }\end{array}$ & & $\checkmark$ & & & & $\checkmark$ \\
\hline 7 & Curb ramp & $\checkmark$ & & $\checkmark$ & $\checkmark$ & & $\checkmark$ \\
\hline 8 & Ramp & $\checkmark$ & & $\checkmark$ & & $\checkmark$ & $\checkmark$ \\
\hline 9 & Boarding ramp & & & & & $\checkmark$ & $\checkmark$ \\
\hline 10 & $\begin{array}{l}\text { Accessible routes, Pedestrian for } \\
\text { PwDs or Obstacle free routes }\end{array}$ & $\checkmark$ & $\checkmark$ & $\checkmark$ & $\checkmark$ & & $\checkmark$ \\
\hline 11 & Entrance & $\checkmark$ & & & & & \\
\hline 12 & Doors, doorway and gate & $\checkmark$ & $\checkmark$ & $\checkmark$ & & & $\checkmark$ \\
\hline 13 & Stair & $\checkmark$ & & $\checkmark$ & $\checkmark$ & $\checkmark$ & $\checkmark$ \\
\hline 14 & Stairway & $\checkmark$ & & & & & \\
\hline 15 & Directional sign & $\checkmark$ & & $\checkmark$ & $\checkmark$ & $\checkmark$ & $\checkmark$ \\
\hline 16 & Floor or ground surfaces & $\checkmark$ & & $\checkmark$ & $\checkmark$ & $\checkmark$ & $\checkmark$ \\
\hline 17 & $\begin{array}{l}\text { Highlighting of transparent } \\
\text { obstacle }\end{array}$ & $\checkmark$ & & $\checkmark$ & & & \\
\hline 18 & Handrail & $\checkmark$ & & $\checkmark$ & & $\checkmark$ & $\checkmark$ \\
\hline 19 & Lighting & $\checkmark$ & & $\checkmark$ & & $\checkmark$ & \\
\hline 20 & Pathway & & & $\checkmark$ & & $\checkmark$ & \\
\hline 21 & Pedestrian crossing & & & $\checkmark$ & & & $\checkmark$ \\
\hline 22 & Public address system & $\checkmark$ & $\checkmark$ & & $\checkmark$ & & \\
\hline 23 & Toilet or restroom & $\checkmark$ & $\checkmark$ & $\checkmark$ & $\checkmark$ & $\checkmark$ & $\checkmark$ \\
\hline 24 & Platform & $\checkmark$ & $\checkmark$ & & & & \\
\hline 25 & $\begin{array}{l}\text { DetecTable warning surface or } \\
\text { Tactile ground surface indicators }\end{array}$ & $\checkmark$ & & & $\checkmark$ & $\checkmark$ & \\
\hline 26 & Turnstile & & & & $\checkmark$ & & \\
\hline 27 & $\begin{array}{l}\text { Protecting of protruding and } \\
\text { overhead objects }\end{array}$ & $\checkmark$ & & & $\checkmark$ & & \\
\hline 28 & Maneuver area for wheelchair & $\checkmark$ & & & & $\checkmark$ & \\
\hline 29 & $\begin{array}{l}\text { Resting point every } 60 \text { meters with } \\
\text { seat }\end{array}$ & & & & $\checkmark$ & $\checkmark$ & \\
\hline 30 & $\begin{array}{l}\text { Waiting area with } 2 \text { seats available } \\
\text { to PwDs }\end{array}$ & $\checkmark$ & & & & $\checkmark$ & $\checkmark$ \\
\hline 31 & Braille or Visual information & $\checkmark$ & $\checkmark$ & & & $\checkmark$ & \\
\hline \multirow[t]{2}{*}{32} & $\begin{array}{l}\text { automatic door to protect between } \\
\text { rail / train and platform }\end{array}$ & & & & & & $\checkmark$ \\
\hline & Total & 26 & 9 & 16 & 15 & 16 & 16 \\
\hline
\end{tabular}

As the results of comparing standard in Table 4, among other ADA provided the highest number of compulsory facilities at 26 facilities. Even though other standards such as UN, CA and DSAPT are providing almost the same number of compulsory facilities but they indication of compulsory facilities are somewhat different. For the second group "optional facilities" is indicated by different standards can be compared as shown in Table 5. below. 
Table 5. Comparison of optional railway station facilities.

\begin{tabular}{|c|l|c|c|c|c|c|c|}
\hline Item & \multicolumn{1}{|c|}{ Facility name } & $\mathbf{A D A}^{\mathbf{1}}$ & $\mathbf{E U}^{\mathbf{2}}$ & $\mathbf{U N}^{\mathbf{3}}$ & $\mathbf{C A}^{\mathbf{4}}$ & $\mathbf{D S A P T}^{\mathbf{5}}$ & $\mathbf{T h a i}^{\mathbf{6}}$ \\
\hline 1 & Telephone & $\checkmark$ & & & $\checkmark$ & & $\checkmark$ \\
\hline 2 & $\begin{array}{l}\text { Ticketing, information desks and } \\
\text { customer assistance points }\end{array}$ & & $\checkmark$ & & & & $\checkmark$ \\
\hline 3 & $\begin{array}{l}\text { Ticketing and automatic fare } \\
\text { vending }\end{array}$ & $\checkmark$ & & & $\checkmark$ & & $\checkmark$ \\
\hline 4 & Elevator or lift & $\checkmark$ & & & $\checkmark$ & $\checkmark$ & $\checkmark$ \\
\hline 5 & Escalator & $\checkmark$ & & & $\checkmark$ & & $\checkmark$ \\
\hline 6 & Fire alarm system & $\checkmark$ & & & $\checkmark$ & $\checkmark$ & \\
\hline 7 & Platform lift & $\checkmark$ & & & $\checkmark$ & & \\
\hline 8 & Drinking fountain & $\checkmark$ & & & $\checkmark$ & & \\
\hline 9 & Control operating mechanism & & & & $\checkmark$ & & \\
\hline 10 & Landscaping and planting & & & & $\checkmark$ & & \\
\hline 13 & Food and drink service & & & & & $\checkmark$ & \\
\hline 14 & Belonging service & & & & & & $\checkmark$ \\
\hline 15 & Automatic or power assist door & & & & & & $\checkmark$ \\
\hline 16 & Elevated platform & & & & $\checkmark$ & & \\
\hline 17 & Automatic teller machines & $\checkmark$ & & & & & \\
\hline 18 & Two way communication system & $\checkmark$ & & & & & \\
\hline 19 & Change machine & $\checkmark$ & & & & & \\
\hline
\end{tabular}

Note:

1. Americans with Disabilities Act (ADA)

2. European Union Agency for Railway

3. Accessibility for the Disabled - A Design Manual for a Barrier Free Environment

4. Disability Standards for Accessible Public Transport 2002

5. 2007 Facility Accessibility Design Standard (Canada)

6. The ministerial regulations for facilitation of disabled or handicapped and elderly facilities 2013 (Thailand).

Some facilities are additionally recommended for the convenience of the passengrers and for improving accessibility. The additional facilities are; 1) Automatic ticket gate 2) Cycle lanes on the road leading up to station access 3) Transit Hot Lines with human operators 4) Traveler's aid 5) Car rentals and car sharing 6) Bike sharing 7) Wireless internet access 8) Public lockers 9) Retail

It was found that the compulsory, optional and additional facilities for all are gathered as 56 facilities as shown in Table 4, 5 and additional requirement.

The researcher has designed the simple question to find out the approaches of 1) Compulsory 2) Optional 3) not required. These 3 categorized facilities are to be assessed the importance by respondents. The data was analyzed by using Frequency Index (FI) technique in order to classify facility into 3 categories. Also, FI technique will be employed to rank the importance of each facility. The respondents are required to prioritize the importance of facilities ranging from 1-3. FI technique was categorized on three-point Likert's scale as compulsory, optional and not required and will be calculated according to the following formula Frequency Index (F.I.) (\%)

$$
\sum a\left(\frac{n}{N}\right) * 100 / 3
$$

Where;
$\mathrm{a}=$
Constant weighing that given to response (range from 1 Not required, 2 Optional and 3 Required)
$\mathrm{n}=$ Frequency of the responses
$\mathrm{N}=$
Total number of respondent

The assessment citeria of facility categories are shown in the below table 
Table 6. Criteria of facility assessment

\begin{tabular}{|l|l|}
\hline Category & Frequency Index Percentage \\
\hline Compulsory & $>72.5 \%$ \\
\hline Optional & $<55 \% \leq 72.5 \%$ \\
\hline Not required & $<55 \%$ \\
\hline
\end{tabular}

The follwing table is the results analysis of facilities importance

Table 7. Result of railway station facilities importance assessment

\begin{tabular}{|c|c|c|c|c|c|c|c|}
\hline \multirow{2}{*}{ Item } & \multirow{2}{*}{ Facility name } & \multicolumn{3}{|c|}{ Percent of responses (\%) } & \multirow{2}{*}{ Conclude } & \multirow{2}{*}{$\begin{array}{l}\text { F.I. } \\
(\%)\end{array}$} & \multirow{2}{*}{ Rank } \\
\hline & & Compulsory & Optional & $\begin{array}{c}\text { Not } \\
\text { required }\end{array}$ & & & \\
\hline 1 & Parking & 60.00 & 32.50 & 7.50 & Compulsory & 84.17 & 20 \\
\hline 2 & Street furniture & 30.00 & 60.00 & 10.00 & Compulsory & 73.33 & 40 \\
\hline 3 & $\begin{array}{l}\text { Areas of refuge } \\
\text { Emergency exit and } \\
\text { fire evacuation and area } \\
\text { of rescue assistance }\end{array}$ & 37.50 & 45.00 & 17.50 & Compulsory & 73.33 & 43 \\
\hline 4 & Passenger loading zone & 72.50 & 25.00 & 2.50 & Compulsory & 90.00 & 9 \\
\hline 5 & $\begin{array}{l}\text { Level track crossing at } \\
\text { station or Overpass for } \\
\text { PwDs }\end{array}$ & 62.50 & 35.00 & 2.50 & Compulsory & 86.67 & 14 \\
\hline 6 & Curb ramp & 60.00 & 37.50 & 2.50 & Compulsory & 85.83 & 17 \\
\hline 7 & Ramp & 60.00 & 40.00 & - & Compulsory & 86.67 & 14 \\
\hline 8 & Boarding ramp & 55.00 & 42.50 & 2.50 & Compulsory & 84.17 & 20 \\
\hline 9 & $\begin{array}{l}\text { Accessible routes, } \\
\text { Pedestrian for PwDs or } \\
\text { Obstacle free routes }\end{array}$ & 70.00 & 30.00 & - & Compulsory & 90.00 & 9 \\
\hline 10 & Main entrance & 60.00 & 40.00 & - & Compulsory & 86.67 & 14 \\
\hline 11 & Stairway & 57.50 & 37.50 & 5.00 & Compulsory & 84.17 & 20 \\
\hline 12 & Directional sign & 77.50 & 17.50 & 5.00 & Compulsory & 90.83 & 8 \\
\hline 13 & $\begin{array}{l}\text { Floor or ground } \\
\text { surfaces }\end{array}$ & 65.00 & 32.50 & 2.50 & Compulsory & 87.50 & 13 \\
\hline 14 & $\begin{array}{l}\text { Highlighting of } \\
\text { transparent obstacle }\end{array}$ & 60.00 & 32.50 & 7.50 & Compulsory & 84.17 & 20 \\
\hline 15 & Handrail & 82.50 & 17.50 & 0.00 & Compulsory & 94.17 & 4 \\
\hline 16 & Lighting & 87.50 & 12.50 & 0.00 & Compulsory & 95.83 & 1 \\
\hline 17 & Barrier free pathway & 77.50 & 22.50 & 0.00 & Compulsory & 92.50 & 5 \\
\hline 18 & Pedestrian crossing & 60.00 & 25.00 & 15.00 & Compulsory & 81.67 & 32 \\
\hline 19 & Public address system & 70.00 & 27.50 & 2.50 & Compulsory & 89.17 & 12 \\
\hline 20 & Toilet or restroom & 77.50 & 22.50 & 0.00 & Compulsory & 92.50 & 5 \\
\hline 21 & Platform & 85.00 & 15.00 & 0.00 & Compulsory & 95.00 & 3 \\
\hline 22 & $\begin{array}{l}\text { DetecTable warning } \\
\text { surface or Tactile } \\
\text { ground surface } \\
\text { indicators }\end{array}$ & 57.50 & 42.50 & 0.00 & Compulsory & 85.83 & 17 \\
\hline 23 & Turnstile & 17.50 & 22.50 & 60.00 & Not required & 52.50 & 56 \\
\hline 24 & $\begin{array}{l}\text { Protecting of } \\
\text { protruding and } \\
\text { overhead objects }\end{array}$ & 50.00 & 47.50 & 2.50 & Compulsory & 82.50 & 28 \\
\hline 25 & $\begin{array}{l}\text { Maneuver area for } \\
\text { wheelchair }\end{array}$ & 55.00 & 37.50 & 7.50 & Compulsory & 82.50 & 28 \\
\hline 26 & $\begin{array}{l}\text { Resting point every } 60 \\
\text { meters with seat }\end{array}$ & 45.00 & 47.50 & 7.50 & Compulsory & 79.17 & 35 \\
\hline 27 & $\begin{array}{l}\text { Waiting area with } 2 \\
\text { seats available to PwDs }\end{array}$ & 32.50 & 60.00 & 7.50 & Compulsory & 75.00 & 39 \\
\hline 28 & $\begin{array}{l}\text { Braille or Visual } \\
\text { information }\end{array}$ & 55.00 & 37.50 & 7.50 & Compulsory & 82.50 & 28 \\
\hline 29 & $\begin{array}{l}\text { Automatic door to } \\
\text { protect between rail / } \\
\text { train and platform }\end{array}$ & 60.00 & 32.50 & 7.50 & Compulsory & 84.17 & 20 \\
\hline
\end{tabular}




\begin{tabular}{|c|c|c|c|c|c|c|c|}
\hline \multirow{2}{*}{ Item } & \multirow{2}{*}{ Facility name } & \multicolumn{3}{|c|}{ Percent of responses (\%) } & \multirow{2}{*}{ Conclude } & \multirow{2}{*}{$\begin{array}{l}\text { F.I. } \\
\text { (\%) }\end{array}$} & \multirow{2}{*}{ Rank } \\
\hline & & Compulsory & Optional & $\begin{array}{c}\text { Not } \\
\text { required }\end{array}$ & & & \\
\hline 30 & Telephone & 40.00 & 30.00 & 30.00 & Optional & 70.00 & 49 \\
\hline 31 & $\begin{array}{l}\text { Ticketing, information } \\
\text { desks and customer } \\
\text { assistance points }\end{array}$ & 70.00 & 30.00 & 0.00 & Compulsory & 90.00 & 9 \\
\hline 32 & $\begin{array}{l}\text { Ticketing and } \\
\text { automoatic fare } \\
\text { vending }\end{array}$ & 52.50 & 35.00 & 12.50 & Compulsory & 80.00 & 34 \\
\hline 33 & Elevator or lift & 62.50 & 30.00 & 7.50 & Compulsory & 85.00 & 19 \\
\hline 34 & Escalator & 52.50 & 40.00 & 7.50 & Compulsory & 81.67 & 31 \\
\hline 35 & $\begin{array}{l}\text { Fire alarm system with } \\
\text { light signalling }\end{array}$ & 87.50 & 12.50 & 0.00 & Compulsory & 95.83 & 1 \\
\hline 36 & Platform lift & 50.00 & 42.50 & 7.50 & Compulsory & 80.83 & 33 \\
\hline 37 & Drinking fountain & 35.00 & 42.50 & 22.50 & Optional & 70.83 & 47 \\
\hline 38 & Emergency help point & 75.00 & 25.00 & 0.00 & Compulsory & 91.67 & 7 \\
\hline 39 & $\begin{array}{l}\text { Landscaping and } \\
\text { planting }\end{array}$ & 57.50 & 37.50 & 5.00 & Compulsory & 84.17 & 20 \\
\hline 40 & Food and drink service & 37.50 & 42.50 & 20.00 & Compulsory & 72.50 & 44 \\
\hline 41 & Belonging service & 17.50 & 70.00 & 12.50 & Optional & 68.33 & 50 \\
\hline 42 & $\begin{array}{l}\text { Automatic or power } \\
\text { assist door }\end{array}$ & 45.00 & 27.50 & 27.50 & Compulsory & 72.50 & 44 \\
\hline 43 & Elevated platform & 40.00 & 40.00 & 20.00 & Compulsory & 73.33 & 40 \\
\hline 44 & $\begin{array}{l}\text { Automatic teller } \\
\text { machines }\end{array}$ & 55.00 & 40.00 & 5.00 & Compulsory & 83.33 & 27 \\
\hline 45 & $\begin{array}{l}\text { Two way } \\
\text { communication system }\end{array}$ & 40.00 & 32.50 & 27.50 & Optional & 70.83 & 47 \\
\hline 46 & Change machine & 45.00 & 40.00 & 15.00 & Compulsory & 76.67 & 36 \\
\hline 47 & Mobile garbage bin & 35.00 & 30.00 & 35.00 & Optional & 66.67 & 51 \\
\hline 48 & Automatic ticket gage & 45.00 & 37.50 & 17.50 & Compulsory & 75.83 & 38 \\
\hline 49 & $\begin{array}{l}\text { Cycle lanes on the road } \\
\text { leading up to station } \\
\text { access }\end{array}$ & 25.00 & 45.00 & 30.00 & Optional & 65.00 & 52 \\
\hline 50 & $\begin{array}{l}\text { Transit Hot Lines with } \\
\text { human operators }\end{array}$ & 42.50 & 45.00 & 12.50 & Compulsory & 76.67 & 37 \\
\hline 51 & Traveler's aid & 57.50 & 37.50 & 5.00 & Compulsory & 84.17 & 20 \\
\hline 52 & $\begin{array}{l}\text { Car rentals and car } \\
\text { sharing }\end{array}$ & 15.00 & 57.50 & 27.50 & Optional & 62.50 & 53 \\
\hline 53 & Bike sharing & 17.50 & 30.00 & 52.50 & Not required & 55.00 & 55 \\
\hline 54 & Free WiFi & 37.50 & 40.00 & 22.50 & Optional & 71.67 & 46 \\
\hline 55 & Public lockers & 15.00 & 45.00 & 40.00 & Optional & 58.33 & 54 \\
\hline 56 & Retail & 32.50 & 55.00 & 12.50 & Compulsory & 73.33 & 40 \\
\hline
\end{tabular}

Remark:

1. This research had prioritized only required facilities.

2. The conclusion of each facility is considering from the percentage of Frequency Index (F.I.) should more than $40 \%$.

According to F.I. calculation, the first fifth compulsory facilities can be concluded as Table 8 .

Table 8. Priority importance of facilities

\begin{tabular}{|c|l|c|}
\hline Priority & \multicolumn{1}{|c|}{ Facilities } & Frequency Index (F.I.) \\
\hline 1 & Firm alarm with siren signal and Lighting & $95.83 \%$ \\
\hline 2 & Platform & $95.00 \%$ \\
\hline 3 & Lift & $94.17 \%$ \\
\hline 4 & Directional signage, Barrier-free pathway and Toilet & $92.85 \%$ \\
\hline 5 & Emergency help point & $92.83 \%$ \\
\hline
\end{tabular}

The first fifth of importance facilities are 1) Firm alarm with siren signal and Lighting 2) Platform 3) Lift 4) Directional signage, Barrier free pathway and Toilet 5) Emergency help point. 
The results from prioritizing the important of faciliities also shown that there are 45 compulsory facilities, 9 optional facilities whereas 2 facilities were specified that not required. Regarding to facilities specified that "Not required" from the respondents and they had explained about those facilities as follows

1) Turnstile especially manually-operated type can be seen as an obstacle for accessibility and made it more difficult to enter the place for passengers.

2) Bike Sharing; as Thailand can be considered as a motor-driven country, eventhough biking is encouraged, it supporting facilities, such as extensive bike lane network still by far lacking behind.

Besides, some of the respondents gave the opinion to other facilities such as drinking fountain may not be necessary since the quality of water from drinking fountain may not be fully hygiene. They also gave the opinion to the public telephone may also not necessary because nowadays nearly everyone has a personal mobile phone.

\section{Conclusion}

According to standards and guidelines reviewing in this research, it made the acknowledgment that the facilities are able to improve the accessibility to public transportation. However, those facilities will be work in full efficiency when they were built according to standards and guidelines. The Thai's legislation and standards need to be revised by providing more facilities in details or even provide the facilities list according to a specific type of public transportation station. Accessibility should be improved by providing facilities suit for each type of passengers and the simulation models should be provided for verification.

From the analysis, the researcher has found that there are 56 facilities need to provide for all and using the F.I. method found the 5 items compulsory are priority importance for accessibility to the railway station. Those 5 items are 1) Firm alarm with siren signal and Lighting 2) Platform 3) Lift 4) Directional signage, Barrier free pathway and Toilet 5) Emergency help point as shown in Table 7. Those facilities almost related to accessibility of public transportation. Notwithstanding, the improvement or providing facilities will spend a big budget and may not be able to improve or provided those facilities to all station at the same time. Therefore, this ranking would help to prioritize for improvement or providing those facilities.

Thailand is facing lacking of facilities and some of the existing facilities are not ready to use. The facilities providing or improvement should be considered in order to improve accessibilities to railway station which able to encourage the number of ridership increase, it will be a benefit to sustainable development for rail transportation system in Thailand.

From eight types of respondent shown in Table 3, the researcher found that interviewing with hearing disabilities are most difficult. This is because it required the help of hand language translator at all times. This research would like to express sincere thanks to Ratchasuda College (College for disabled), Mahidol University for facilitating with PwDs during data surveying. The researcher hopes that this research would be useful for improving public transportation facilities to be accessible by all in the near future.

\section{Discussion}

Due to this research is relied on the answer of respondents hence the results shown in Table.6 might be questionabilities to classified them into "Compulsory", "Optional" or "Not required". So these questionabilities might need to survey the data futher.

\section{References}

1. National statistic office, Population and Housing Statistics Report Thailand, (2015)

2. National Center on Elder Abuse, Abuse of Adults with a Disability, (to be published)

3. Eurostat, Disability statistics - prevalence and demographics, available online: http://ec.europa.eu/eurostat/statistics-explained/index.php/Disability_statistics__prevalence_and_demographics 
4. Neena L. Chappell and Cooke H.A, International Encyclopedia of Rehabilitation, Age Related Disabilities - Aging and Quality of Life, Available online:

http://cirrie.buffalo.edu/encyclopedia/en/article/189/

5. Elizabeth A Gardener, Felicia A Huppert, Jack M Guralnik and David Melzer, MiddleAged and Mobility-Limited: Prevalence of Disability and Symptom Attributions in a National Survey, 21(10) 1091-1096 (2006)

6. Economic Intelligence Center, Outlook Quarter 3/2014 Available online: https://www.scbeic.com/th/detail/product/131

7. EIDD Design For All Europe, Inclusive Design Available online http://dfaeurope.eu/

8. Ministry of Interior, Building Control Act 2005 (No.5), 132 32-38 (2005)

9. Ministry of Transportation, The Government Gazzette, Ministerial Regulations of Designing or Equipment Facilities of the Ministry of Transportation to enable people with disabilities to access and utilize, 1304 (2013)

10. Ministry of Social and Human Security, Promote and Improve the Quality of Life of the Disabled Act (2008)

11. World Heath Organization, International Classification of Functioning, Disability, and Health (2007)

12. Ministry of Health, Disability Rehabilitation Act, 108205 (1991)

13. Edwin H.W. Chan, Grace K.L. Lee and Antony T.S. Chan, (2009) "Universal design for people with disabilities: A study of access provisions in public housing estates", Property Management, 27(2), 138-146 (2009)

14. United Nation, Accessibility for the Disabled A Design Manual for a Barrier Free Environment, available online: http:/www.un.org/esa/socdev/enable/designm/.

15. U.S. Department of Transportation, Americans with Disabilities Act (ADA) Standards for Transportation Facilities (2010)

16. National Council on Disability, The Current State of Transportation for People with Disabilities in the United States. Washington (2005)

17. Marc Stickdorn and Jakob Schneider, This is service design thinking, (to be published)

18. Kennedy D.M., Land Transport New Zealand Research Report 344, Personal security in public transport travel in New Zealand: problems, issues \& solutions (2008)

19. European Union, Official Journal of the European Union, COMMISSION REGULATION (EU) No 1300/2014 of 18 November 2014 on the technical specifications for interoperability relating to accessibility of the Union's rail system for persons with disabilities and persons with reduced mobility, L 356/110 (2014)

20. Office of legislative drafting and publishing A.-G. s. D, Disability Standards for Accessible Public Transport 2002 (2011)

21. City of London Canada, Facility Accessibility Design Standard (2007)

22. Xenia Karekla, Taku Fujiyama and NickTyler, Evaluating accessibility enhancements to public transport including indirect as well as direct benefits, 2 92-100 (2011) 